\title{
Ecosystem Services of Chariganga and Arpara Beel in Nadia District, West Bengal: A Geographical Enquiry
}

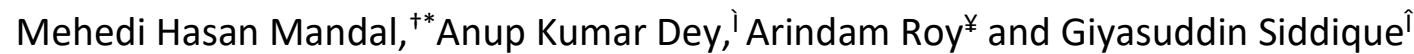

\section{Abstract}

The ecological set up of the deltaic Bengal has immensely been benefitted by the ecosystem services extended by the fresh water wetlands. Along with the diverse ecological benefits, those floodplain wetlands serve the adjacent agrarian community through the provision of free goods and services. The present study has attempted to identify the ecological resources provided by the Chariganga and Arpara Beel and its impact on the livelihood patterns of the rural inhabitants. Both qualitative and quantitative techniques have been used for the study. Ecosystem Service Index (ESI) has been computed to quantify the values of ecosystem services in each categories for dry and wet period. Nearly 33 ecosystem services are identified which have significantly influenced the socio-economic lifestyle of the inhabitants of three adjacent villages like Arpara, Gotpara and Sultanpur but not homogeneously in terms of space, time and status of stakeholders. The computed ESI values reveal that maximum index value in each category of ecosystem services, has been recorded at Chariganga Wetland in both dry and wet season. Moreover fluctuation of ESI between the two season is least at Chariganga Wetland (0.03) compared to Arpara Wetland (0.28). Spatio-temporal variation in availability of resources has conspicuously altered the yearlong utilisation pattern of wetlands' resources, and put noticeable imprint upon the diverse economic activities and cultural practices of the beneficiaries. The seasonal transformation of a large segment of the studied wetlands in wet and dry months has noticeably influenced the livelihood strategies of the natives. As a consequence, dynamism in utilisation pattern and contrasted societal views concerning the wetland-people interdependency has come into existence.

Keywords: Ecosystem Service; Ecosystem Service Index; Ecological Resources; Wetland-people Interdependency

\footnotetext{
${ }^{\dagger}$ Assistant Professor, Department of Geography, Krishnagar Government College, India

${ }^{*}$ Corresponding Email: hasanmhm86@gmail.com

'̀. Phil. Student, Delhi School of Economics, University of Delhi.

Email: akrdey1997@gmail.com

${ }^{\sharp}$ Senior Research Fellow, Department of Geography, The University of Burdwan, West Bengal, India

Email: a.roy.sc@gmail.com

ÎProfessor, Department of Geography, The University of Burdwan, West Bengal, India

Email: gsbu2008@gmail.com

(C) 2020 Mandal et al.This is an Open Access article distributed under the terms of the Creative Commons Attribution License (http://creativecommons.org/licenses/by/2.0), which permits unrestricted use, distribution, and reproduction in any medium, provided the original work is properly cited.
} 


\section{Introduction}

Wetlands, an intermediary zone between land and water spaces, are amongst the most fecund ecosystems of the earth's surface which have benefitted the natural and human environs in multiple ways from global to local sphere (Clarkson et al., 2013). As 'earth's kidneys', wetlands sustain environmental naturalness through carbon sequestration, nutrient cycling, wastewater treatment, regulation of physicochemical properties of water and its purification, flood abatement and groundwater recharge (Zedler \& Kercher, 2005). Besides its ecological importance, wetlands have significantly served the economic and cultural sphere of neighbouring human groups by providing a gamut of tactile goods and impalpable services (Das et al., 2015). Such services are known as 'ecosystem services' that benefit the local ecology as well as the livelihood of the resident in various ways (Maltby \& Acreman, 2011). With new exploration of the wetland's potentialities of resource generation, the livelihood dependency of the human communities (especially the rural folks) on wetland has increased gradually over recent decades (Akwetaireho \& Getzner, 2010). Hence, an inextricable link between the wetlands and its immediate inhabitants has been observed globally as the livelihood strategies of the natives to a large extent have been designed following the availability of wetland ecosystem services. Though the freshwater wetlands of the lower Gangetic floodplains have positively alimented the cultural mosaic as well as ecological set up of the area, their immense services are poorly evaluated and studied by the academicians (Das et al., 2015). The real consequences of those water bodies, their resource potentialities and future scope of utilisation have remained behind the veil of ignorance. The floodplain wetlands of lower Gangetic Plain are now facing several threats despite their diverse range of ecosystem services (Mandal et al., 2018).

The present study begins with a brief literature review to identify the lacuna of the previous research followed by the objectives of the study.
The study then discusses methodology adopted for this research. The concluding remarks have been drawn after proper analysis of the results obtained from the discussion.

\section{Brief Literature Review}

'Ecosystem Services' refer to the array of natural goods and services derived from the ecosystems which have assisted the human society for socioeconomic betterment (Bolund \& Hunhammar, 1999). Millennium Ecosystem Assessment (2005) has broadly categorised these services into four sub-groups, that is, provisioning (tangible goods - satisfying diverse materialistic and economic needs), regulating (benefits obtained from the regulation of ecosystem processes), supporting (internal processes-to sustain general functioning and pliability of ecosystem) and cultural (intangible and immaterial benefits satisfying socio-cultural and religious needs) services. Several scholars all over the world have attempted to identify, quantify, evaluate and understand the importance of such services of different wetlands at various scales and perspectives (Banerjee, 2018). Majority of them have been involved in assessing the total economic value (TEV) of such services encompassing the 'Use values' (that is, materialistic value) and 'Non-use values' (that is, existence value, altruistic value and bequest value) by adopting diverse methods (Brander et al., 2010; Sharma et al., 2015; Emerton, 2015; Mangi, 2016; Baral et al., 2016). The economic value of provisioning goods may be logically assumed by market prices. In contrast, the estimation of the value of the other three categories is convoluted and doubtful due to the non-marketability of those services (Barbier et al., 2011).

Despite the significant contribution of the freshwater wetlands of the lower Gangetic plain in the cultural and ecological sphere of the area, their invaluable services are poorly appraised by the academicians. Recently, few studies (Bala \& Mukherjee, 2011; Ghosh, 2016; Saha, 2016; Mandal \& Siddique, 2018) have been conducted to assess the water quality, resource potentialities as well as the biological resources 
of some sweet water wetlands of the area. Mukherjee (2008) have attempted to appraise the economic valuation of a wetland of undivided Bardhaman district from multiple uses like wetland cultivation, irrigation, fisheries, jute retting, and fodder collection etc. while Das et al., (2015) have analysed the factors that influence the household use of three wetlands from three physiographically distinct regions of West Bengal. Both these research works find how the wetland products help the rural people in sustaining their life around the wetlands.

But, no systematic research has been conducted before to identify and analyse the importance of the extended ecosystem services of Chariganga and Arpara Beel along with its spatiotemporal variation and utilisation pattern. As a consequence, the wetland-people association of these two wetlands is still remain unexplored. Due to the dearth of any sorts of analytical studies following objectives have been set up for the present study:
- to evaluate the ecosystem services and their dynamicity extended by the concerned wetlands; and

- to discuss the interrelationship between the extended services and the socioeconomic livelihoods of the local inhabitants

\section{The Study Area}

The selected wetlands, namely Chariganga and Arpara Beel are located on the left bank of the River Bhagirathi in the moribund part of the lower Gangetic deltaic plain (Bagchi, 1944). Administratively, the area comes under the Nakashipara Block of Nadia District, West Bengal. Genetically, these two oxbow lakes have been formed by the lateral shifting of the river course along with simultaneous erosionaccretion processes. These two remnants of River Bhagirathi still receive a huge influx of discharge from the River Bhagirathi during monsoon. However, the larger portion of these wetlands remains dry during most of the time of the year.

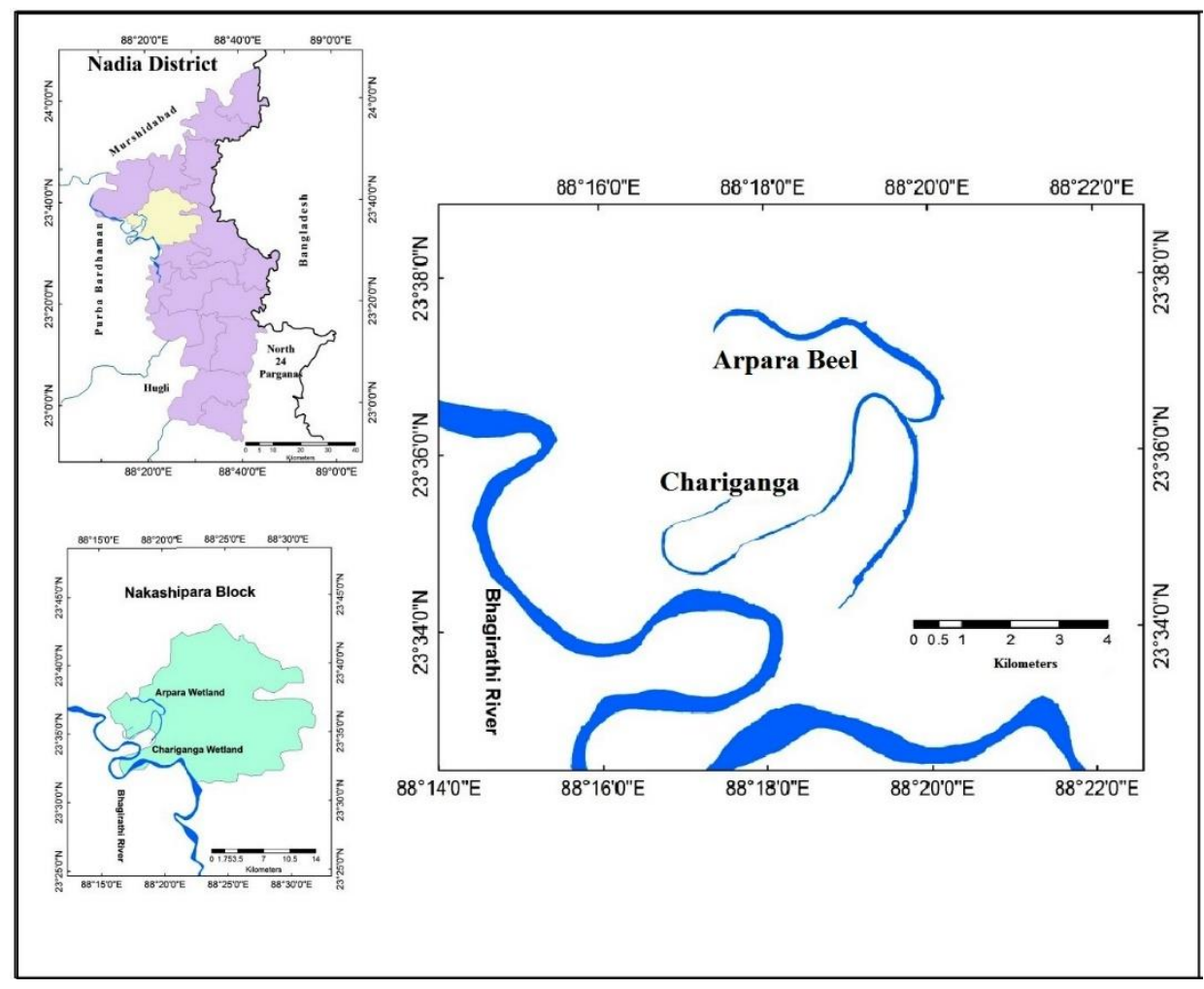

Figure 1: Location of the Study Area Source: Prepared by the Authors from Google Earth Image, 2019 


\section{Database and Methodology}

The study is based on both the qualitative and quantitative data acquired through empirical observation and interaction with the stakeholders. To understand the dynamism in utilisation pattern, household surveys were conducted in three adjacent villages namely Sultanpur, Gotpara and Arpara by selecting 50 households from each village through purposive random sampling in dry (April-May) and wet months (September-October) of 2019. The families who have directly used the wetland resources were selected for in-depth interviews. Besides, three focus group discussions, containing ten aged people ( $>50$ years) in each group, have been conducted in each village for understanding the dynamism in societal perspectives. Bengali language was used during the focus group discussions and interviews because it is the mother tongue of both surveyors and respondents. Therefore, no difficulties were faced regarding understanding the opinion and perception of the local people during discussions. Thus collective views of the stakeholders have been reflected in the study. A false name (Alok Halder) is used (for security purposes) in the discussion section to unveil the specific perception of that people or community. Moreover, ESI was adopted separately for each wetland in two different seasons to calculate the spatio-temporal dynamisms of ecosystem services (Everard et al., 2019). Each service has been transformed into numeric score on a scale ranges from 'significantly positive' (++) through 'neutral' (0) to 'significantly negative' (-) and 'unknown' (?) based on the surveyors' understanding of the stakeholders' words (Table 1). Finally, the index value has been acquired using the formula below:

$$
E S I=\frac{\sum\left(n_{+1.0}+n_{+0.5}\right)+\left(n_{-1.0}+n_{-0.5}\right)}{\sum n_{\text {total }}}
$$

\begin{tabular}{|c|c|c|c|c|c|c|}
\hline $\begin{array}{c}\text { Assigned } \\
\text { Importance }\end{array}$ & $\begin{array}{c}\text { Significantly } \\
\text { Positive }\end{array}$ & Positive & Neutral & Negative & $\begin{array}{c}\text { Significantly } \\
\text { Negative }\end{array}$ & Unknown \\
\hline $\begin{array}{c}\text { Importance } \\
\text { score }\end{array}$ & ++ & + & 0 & - & - & $?$ \\
\hline $\begin{array}{l}\text { Numerical } \\
\text { value }\end{array}$ & 1.0 & 0.5 & 0 & -0.5 & -1.0 & $\begin{array}{c}\text { Exclude from } \\
\text { analysis }\end{array}$ \\
\hline
\end{tabular}

\section{Results and Discussion}

\section{Ecosystem Services of the Selected Wetlands}

A sum of 33 ecosystem services (Table 2) extended by Chariganga and Arpara Beel, have been identified. 18 of 33 services (54.55\%) have directly benefitted the rural people, while another 11 services (33.33\%) have influenced indirectly. Rest four (12.12\%) services have positively served the nearby rural folks through both ways.

Nearly $24.24 \%$ of the total services are the provisioning services, which have a considerable contribution to the economic life of the communities. The rural folks collect potable water, fish, fodder, medicinal herbs, clay/soil and humus for domestic consumption as well as selling in the market. The impoverished, landless people with a low level of literacy have revealed a greater degree of extraction and utilisation of wetland resources compared to their counterparts. Hence, these two wetlands play a crucial role in the livelihood of socially and economically marginalised sections of the community. Primarily two types of hydrophytes-patighas (Sorghum bicolor) and gyama (Actinoscirpus grossus) are commonly collected to feed the cattle. Besides, geri-gugli (Littorina littorea), a species of small edible snail, is also collected for the poultry birds. Various species of sweet water fishes are frequently harvested for the combined purpose of households' 
consumption and selling in the market. These prosperous fishing grounds help sustain the fishing activities of a sizable section of the local community throughout the year. Concurrently, the water is used as the chief sources of irrigation water for jute/ paddy (Boro) cultivation in the dry season.

On the contrary, $30.30 \%$ services are regulating in nature, which has indirectly influenced the livelihood designs of the natives. These environmental functioning factors have a noticeable impact on the ecological structure even beyond the area. Both these wetlands help combat frequent floods by retaining a huge amount of excess water during the monsoon as well as recharge groundwater throughout the year.

Supportive services share the maximum percentage $(33.33 \%)$ of provided services, whereas the cultural services comprise the least (12.12\%).A substantial stretch of both of these wetlands become surfaced in the dry season, which has extensively been used as pasture land and fertile cropland for jute and paddy cultivation. Concurrently, they act as the home of diverse flora and fauna, especially for diverse avian species. The authors have identified a total of 37 wetland birds' during their field visits. The extended cultural services have an important role in the social, spiritual and psychological niches. The locals have ingrained credence on the purity of those wetlands' water, and therefore the consecrated water is used for religious rituals and idol immersion throughout the year. The natural beauty of those wetlands facilitates recreation to the inhabitants as well as the outsiders.

\begin{tabular}{|c|c|c|c|c|}
\hline & $\begin{array}{l}\text { SI. } \\
\text { No. }\end{array}$ & Goods/Services & Description & Remarks \\
\hline \multirow{8}{*}{ 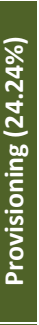 } & 1 & Food & Used for household consumption and market sales & \multirow{7}{*}{$\begin{array}{c}\text { Direct } \\
\text { benefit }\end{array}$} \\
\hline & 2 & Irrigation & Paddy and jute irrigation in different periods & \\
\hline & 3 & Clean Water & Used for food preparation & \\
\hline & 4 & Forage & Used to feed the cattle and poultry birds & \\
\hline & 5 & Fuel & Dry hydrophytes are used as a source of energy & \\
\hline & 6 & Humus & Used as natural fertiliser in farmland & \\
\hline & 7 & Clay/Soil & Used as a building material & \\
\hline & 8 & Medicinal Herbs & $\begin{array}{l}\text { Collection of various aquatic plants like Swamp weeds (Hygrophila auriculata) } \\
\text { and Water Spinach (Ipomoea aquatica) with medicinal value }\end{array}$ & Both \\
\hline \multirow{10}{*}{ 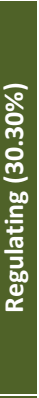 } & 9 & Air Purification & Purifies air by absorbing the contaminants & \multirow{10}{*}{$\begin{array}{l}\text { Indirect } \\
\text { benefit }\end{array}$} \\
\hline & 10 & Nutrient Cycling & Recycles and preserves nutrients & \\
\hline & 11 & Water Regulation & Enhances groundwater storage & \\
\hline & 12 & Flood Control & Combats floods in monsoon by trapping excess water & \\
\hline & 13 & Erosion Regulation & Restricts soil erosion by checking run-off & \\
\hline & 14 & Water Purification & Purifies water by waste treatment and removing pollutants & \\
\hline & 15 & Noise and Visual Buffering & Acts as a noise reduction interface & \\
\hline & 16 & Waste Treatment & Recycles waste as nature's 'kidneys' & \\
\hline & 17 & Local Climatic Regulation & Absorbs heat and carbon; reduces the temperature of the environ & \\
\hline & 18 & $\begin{array}{l}\text { Production of Atmospheric } \\
\text { Oxygen }\end{array}$ & Improves air quality by maintaining $\mathrm{CO}_{2}-\mathrm{O}_{2}$ balance & \\
\hline \multirow{11}{*}{ 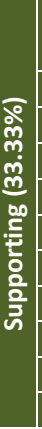 } & 19 & Habitat for Biota & Protects biological diversity & $\begin{array}{l}\text { Indirect } \\
\text { benefit }\end{array}$ \\
\hline & 20 & Soil Formation & Produces bog or peat soil & \multirow[t]{2}{*}{ Both } \\
\hline & 21 & Biomass Production & Decomposed hydrophytes especially water hyacinth & \\
\hline & 22 & Cattle Bathing & Cleaning of domestic animals & \multirow{11}{*}{$\begin{array}{l}\text { Direct } \\
\text { benefit }\end{array}$} \\
\hline & 23 & Pasture Land & Dry wetlands' bed used as grazing ground during dry season & \\
\hline & 24 & Duck Rearing & Provides enrich natural habitat for ducks & \\
\hline & 25 & Jute Retting & Essential for fibre extraction: reduces production expenditure & \\
\hline & 26 & Bathing & Daily/ occasionally & \\
\hline & 27 & Washing & Frequently used for washing clothes and utensils & \\
\hline & 28 & Waste dumping & Used as a container for disposal of waste & \\
\hline & 29 & Agricultural Field & Large parts of the wetlands are used as fertile land during dry season & \\
\hline \multirow{4}{*}{ 들 } & 30 & Aesthetic Value & Enhances the natural beauty that promotes tourism & \\
\hline & 31 & Religious Value & The 'sacred' water used for spiritual purposes and immersion of earthen idols & \\
\hline & 32 & Social Bonding & Acts as a social space for interaction, activities and cohesion & \\
\hline & 33 & $\begin{array}{l}\text { Recreational Tourism and } \\
\text { Educational Visit }\end{array}$ & $\begin{array}{l}\text { Arrival of tourists encourages hotel business and generates new job } \\
\text { opportunities, Visit of researchers for academic purposes }\end{array}$ & Both \\
\hline
\end{tabular}




\section{Temporal Variation in Availability of Services}

The computed ESI values of Chariganga and Arpara Beel have exhibited significant differences in all categories of services in two contrasting seasons of the year. The maximum index value in all categories of services has been recorded for Chariganga wetland in both seasons (Table 3 ). In totality, the Chariganga wetland has recorded the value of 0.61 and 0.58 in dry and wet seasons respectively, which are comparatively much higher than the value of 0.14 and 0.42 for Arpara Beel. Despite being located within a homogeneous region, the unique and typical geographical feature of these two wetlands has generated the variability in the provision of ecosystem services. The Arpara Beel becomes totally parched and converted into arable and pastoral land during the dry times owing to the permanent detachments from the prime river course. In contrast, the larger segment of Chariganga remains full of water throughout the year.

As a consequence, the Arpara Beel has failed to provide absolute numbers of services during the dry spell and naturally, displays insignificant ESI value during that time (Table 3). Moreover, in those periods, the Beel has become unable to serve any common environmental services and thus have recorded the lowest ESI value of -0.15 in regulating category. On the contrary, the provision of services by the Chariganga wetland is less uninterrupted throughout the year due to its perennial condition.

The situation gets changed during monsoon when both these two wetlands reach in a bank full state due to the massive inflow of river water. Under such circumstances, the capability of Arpara Beel to provide various goods/services increases to a great extent and the inter-wetland gap in service provision gets noticeably reduced, especially in provisioning and regulating categories. For example, the difference in ESI value between the selected wetlands has been found maximum in the dry season (0.65) for regulating service category. In contrast, the deviation has become reduced to the minimum $(0.05)$ in the wet season (Figure2).

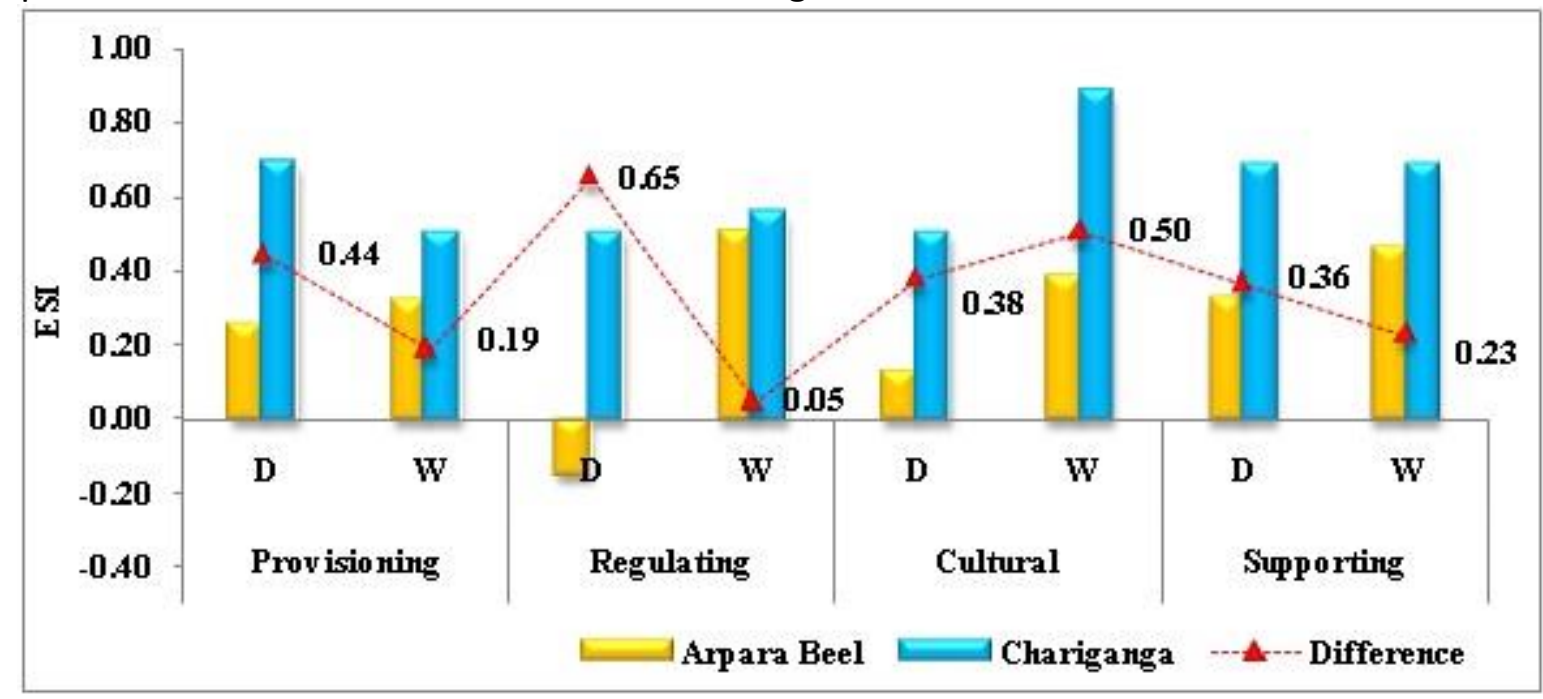

Figure 2: Variation and Inter-Wetland Differences of ESI Values in Dry and Wet spell Source: Computed by the Authors

The seasonal alteration in the physical state of the wetlands has created such distinct differences in the availability of services in two different seasons, which in turn shaped the utilisation pattern and the societal perspectives. For example, in the case of Arpara Beel, the 
difference in the value of regulating service in two seasons is maximum (0.65) due to the complete transformation from filled state to waterless condition or vice-versa (Figure 3). On the contrary, the Chariganga has recorded an insignificant difference of 0.05 in regulating services and no difference in supporting services owing to the almost unchanged physical characteristics. Moreover, the Arpara Beel has recorded least differences of 0.06 in provisioning

\begin{tabular}{|c|c|c|c|c|c|c|c|c|c|c|}
\hline \multirow[t]{2}{*}{ Wetlands } & \multicolumn{2}{|c|}{ Provisioning } & \multicolumn{2}{|c|}{ Regulating } & \multicolumn{2}{|c|}{ Cultural } & \multicolumn{2}{|c|}{ Supporting } & \multicolumn{2}{|c|}{ Total } \\
\hline & D & $\mathbf{W}$ & D & $\mathbf{W}$ & D & $\mathbf{W}$ & D & $\mathbf{W}$ & D & $\mathbf{W}$ \\
\hline Arpara Beel & 0.25 & 0.31 & -0.15 & 0.50 & 0.13 & 0.38 & 0.32 & 0.45 & 0.14 & 0.42 \\
\hline Chariganga & 0.69 & 0.38 & 0.50 & 0.55 & 0.50 & 0.88 & 0.68 & 0.68 & 0.61 & 0.58 \\
\hline
\end{tabular}

service categories due to the consistency in the availability of material resources along with the addition of fishes in the wet period. In the case of the Chariganga, the ESI value has recorded the highest difference in cultural services in two seasons, mainly due to excessive idol immersion during the wet period (September-October), which is also the prime festive season of the area.

D: Dry Period; W: Wet Period

Source: Computed by the Authors

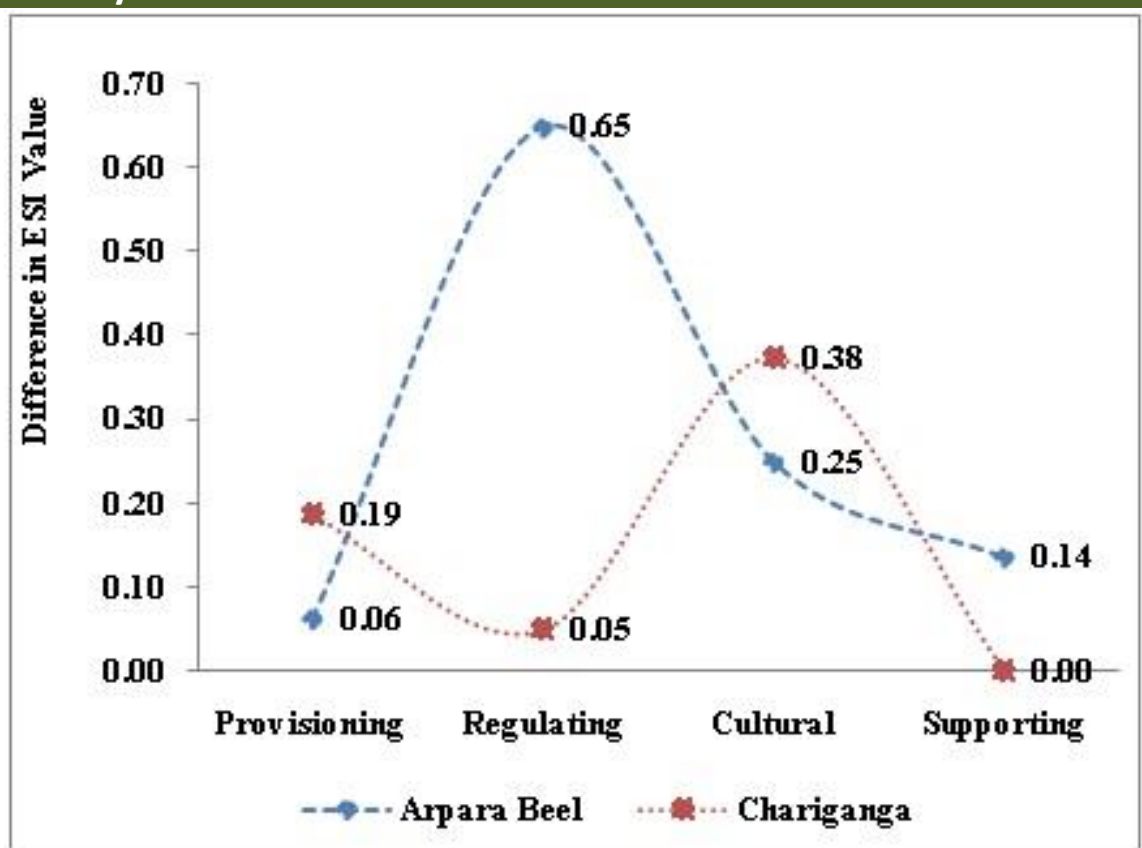

Figure 3: Differences in Category-wise ESI values in Dry and Wet Season Source: Computed by the Authors

\section{Dynamism in Utilisation: Wetland-People Association}

The study reveals the inextricable link between the wetlands and inhabitants residing on the banks as their livelihood strategies revolve around the available wetland services. Both the wetlands are used for multiple purposes. The findings show that the local populace has used these two wetlands as many as 14 ways with marked temporal variation in the mode and extent of utilisation of wetland resources. The following diagram (Figure 4) has revealed the temporal variation of utilisation of the concerning wetlands. As stated earlier, the drastic change in the watery state of the Arpara Beel has significantly altered the utilisation pattern of the concerned Beel. On the contrary, the utilisation of the Chariganga has shown negligible variation due to the yearlong stability of the waterlogged part. Figure 4 has clearly depicted the comparatively higher variability of utilising the Arpara Beel in different seasons. For 
example, the Chariganga is used in 13 ways during the dry period of the year, whereas at that same time, Arpara Beel can be used for only six purposes like wetland agriculture, collection of food, fuel, fodder, clay and humus etc. But, when the Beel gets filled up by the inflow of river water during the rainy season, the adjacent rural folks utilise the Beel by 12 different ways such as bathing, washing cloths and utensils, fishing, jute retting, collection of water for cooking and religious purposes, collection of food, fuel, fodder, clay and humus.
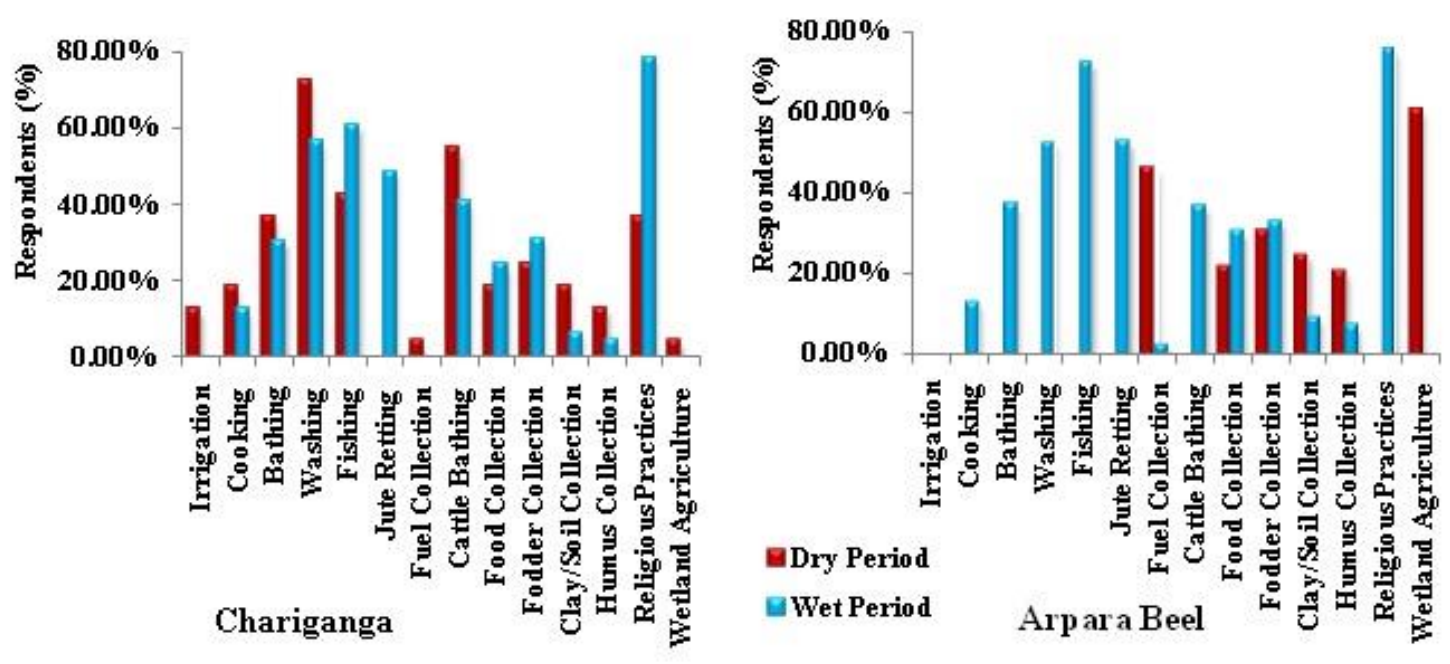

Figure 4: Temporal Variation of Utilisation of the Wetlands Source: Computed by the Authors

The socio-economic livelihood of the local rural communities primarily depends on the degree of availability, accessibility, quality and utility of the services. Both these two 'resource pools' (wetlands) appreciably support the principal economic activities that is, crop cultivation and fishing, on which nearly $81.44 \%$ of the residents depend for livelihood earning (Figure 5). Figure 4 has also revealed that nearly $60.32 \%$ of the respondents have used the dry bed of Arpara Beel as crop fields. In contrast, only $2.32 \%$ of respondents are engaged in wetland agriculture along the marshy banks of the Chariganga. Nearly $42.50 \%$ of respondents do fishing in the stagnant water of Chariganga in the dry season, which has been increased to $60.72 \%$ in the wet spell. Fishing activities in the Arpara Beel is completely closed during the dry season of the year, but about $72.12 \%$ of the inhabitants fish in this beel during the rainy season. Nearly $18.36 \%$ of the respondents' families have collected lakes' water for cooking purposes. A large proportion of respondents have used these lakes for washing, cattle bathing and jute retting.
Though the stagnant muddy water produces low-quality jute fibre, but with no alternatives, the farmers are compelled to use these turbid water bodies for jute retting. The intrusion of slow-moving freshwater from the River Bhagirathi during monsoon converts these standing water bodies to the producing ground of best quality 'golden fibre', whose market price is very high. The lakes are also used for collection of fodder, fuel wood (like garnering of dried branches, stems of jute etc.) and a wide variety of green leafy vegetables [like Kalmi (Ipomoea aquatic), Halencha (Enhydra fluctuans), Sushni (Marsilea quadrifoliata), Senchi (Alternanthera sessilis), Shola (Aeschynomene indica), Kochu (Colocasia esculena). Ghechu (Aponogeton spp.) etc.]. Nearly $24 \%$ of villagers, especially the poor ones, have frequently consumed such wetland edible plants and periwinkles (Gugli) in daily diet. Nearly $42.32 \%$ of people have collected the dry grasses as fuel. The collected humus $(8.03 \%)$ is used as fertiliser in the cropland, whereas clayey soil or mud has been used to construct mud houses or to polish mud walls and clay 
stove/oven. Almost $11.44 \%$ of local population has extracted clay/mud for repairing the kutcha houses. There remains an ingrained belief in the study area that the water in the River Bhagirathi is pure and holy. The inflow of 'holy' water from the River Bhagirathi during the monsoon makes these two wetlands conducive for practising religious rituals and customs. Nearly $78.12 \%$ of the inhabitants have collected the 'pure' water during that period. Even nearly $34.48 \%$ of the respondents, mostly old persons take a regular bath in these water bodies for religious purity. It is noteworthy that most of the agricultural population (48\%) are involved in jute cultivation in the dried segment and jute retting in the stagnant water, followed by paddy (36\%) and mustard (16\%).

These water bodies, especially the Chariganga pose recreational value with pleasant beauty in and around, which bear prospect of rural tourism. Table 4 demonstrates the economic benefits accrued by the local people via utilisation of 'free' goods and services that help reduce daily expenditure and saves money for fulfilling other needs of life. Table 4 also presents the estimated value of the complementary goods/services of the wetlands in terms of monetary or other relevant units based on the opinion of the beneficiaries.

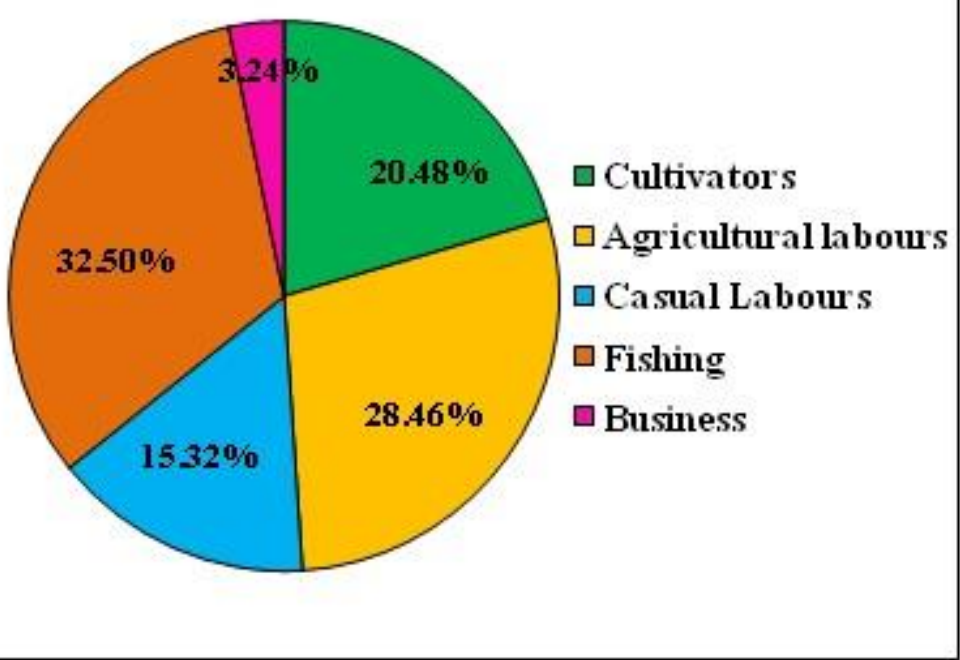

Figure 5: Occupational Structure of the Respondents Source: Primary Survey, 2019

\begin{tabular}{|l|l|}
\hline Table: 4 Valuation of Wetlands' Goods/Services \\
\hline Goods/Services & Estimated Value \\
\hline Irrigation & INR 480/Bigha/Day \\
\hline Cooking & $\mathbf{8}$ Itr./Household/ Day \\
\hline Bathing & 10 Itr./Person/ Day \\
\hline Washing & 30 Itr./Household/ Day \\
\hline Cattle Bathing & 30 Itr./Cattle/Household \\
\hline Jute Retting & INR 500./Household/Season \\
\hline Fodder & INR $\mathbf{8 0 0} /$ Household/Year \\
\hline Fuel wood & $\mathbf{1 0}$ Kg/Household/Season \\
\hline Fishing & INR 3000/Family./Season \\
\hline Wetland Agriculture & INR 2000/Household/Year \\
\hline Building Materials & INR 30/bag/Household \\
\hline Source: Primary Survey, 2019 &
\end{tabular}




\section{Emerging Conflicts Regarding the Conservation} Issue

It should be mentioned that these services are not homogenously beneficial to all the local communities owing to the distinctive nature of services and the differential socio-economic needs. The dried segments of the wetlands during the pre and post-monsoon periods provide vast fertile tract to produce crops like paddy, jute and mustard by the nearby cultivators. Moreover, wetlands also provide grazing grounds which support the livelihood of local people. Thus, the agrarian people have become dependent upon the conferred productive land, pastoral ground and irrigation water from these wetlands. On the contrary, the months of monsoon are bestowed as a boon to the fisher community. A huge influx of freshwater from the river or the accumulation of excess water in those wetlands during that period encourages the fishing activities, which have supported and cherished the livelihood of the Halder community (local fisher group). However, it is noteworthy that fish production has gradually declined in the study area. The local fishers and the members of the local fishing cooperatives (like Halder Matsa Samiti and Kutirpara Matsa Samiti) have opined that laxity in freshwater flow, propagation of water hyacinths (Kochuripana or Eichhornia crassipes) or water lettuce (Tokapana or Pistia) and uses of chemical fertiliser in the adjacent farmlands have intensified the decrease in fish production over past years. Mr. Alok Halder, a 57 years old fisherman, reacted: "the water bodies get untidy, the water has become grubby due to the damnable human oppression. How to get more fish?'

The findings of this study thus suggest that the seasonal alteration of these wetlands, especially in case of Arpara Beel, has put drastic as well as dramatic impact upon the cultural fabric of the area. The periodical changing status of the wetland has effectively influenced the wetlandpeople relationship and also shaped the contrasting discourses concerning the conservation of the wetlands. The complex interrelationship between human society and nature gives rise to various power-plays, either in the obvious or inherent form within the social sphere of an area (Mukherjee, 2008). The contradiction in economic class-based utilisation pattern of both the wetlands inevitably generates a complex power-play concerning the issue of conservation in the study area. Both the farmers and the fisher communities are willing to preserve the wetlands in such a way which can satisfy their economic interests maximally. Despite the unequal accessibility of converted land and irrigation water, surprisingly, a greater proportion of the farmers of all stratums is in favour of minimising the extent of wetlands' area and transforming their larger portion into fertile farmland perpetually through artificial dissociation from the river course. According to them, the economic profitability of the converted fertile land is much higher than the overall earning from these wetlands (Primary Survey, 2019).

On the contrary, the fisher community are interested in keeping the wetlands into fully wet condition. They have argued for a free flow of water throughout the year in these wetlands which may further prosper their living through fishing. They have further opined that the scarcity of freshwater flow from the river course has diminished the availability of a variety of fishes and other aquatic creatures (like prawn, small crab, snail etc.) which have negatively affected their sustenance of livelihood. Naturally, they are in favour of restoring these wetlands through excavating new connector channels up to the prime river course.

Despite the squeezing opportunities of fishing, the fishermen have refused to shift from their occupation, which they believe is determined by the division of labour, following the caste system. They are desperate enough to continue their ancestors' tradition of fishing. The agricultural people, on the other, are certainly opportunists, who are determined to utilise any sorts of possibilities extended by these wetlands.

\section{Conclusion}

This study aimed at examining ecosystem services of Chariganga and Arpara Beel in the 
Nadia District of West Bengal. The findings suggest that the ecosystem services of these two wetlands have a distinctive impact on the livelihood strategies of the adjacent rural people. But the seasonal changes of the concerned wetlands generate certain dynamism in utilisation pattern, which lead towards a unique power-play equation associated with conflict of interests between two major occupational communities, that is, farmers and fishers. Both the communities have an influential role in determining the conservation measures, and therefore no one can be kept outside from the planning. Therefore, an exigency for comprehensive and multidimensional management strategy is felt to conserve these wetlands, without compromising the present degree of use. Concurrently, it is further needed to frame an apt policy for equitable distribution of the benefits of the wetlands services among different sections of the society.

\section{References}

Akwetaireho, S., \& Getzner, M. (2010). Livelihood dependence on ecosystem services of local residents: A case study from Mabamba Bay wetlands (Lake Victoria, Uganda). International Journal of Biodiversity Science, Ecosystem Services \& Management, 6(1-2), 7587.https://doi.org/10.1080/21513732.2010.521 139

Bagchi, K. (1944). The Ganges Delta ( $1^{\text {st }}$ ed.). University of Calcutta

Banerjee, D. (2018). Ecosystem services and environmental valuation: Need and application. Indian Journal of Landscape Systems and Ecological Studies, 41(1), 155-168.

Baral, S., Basnyat, B., Khanal, R., \&Gauli, K. (2016). A total economic valuation of wetland ecosystem services: An evidence from Jagadishpur Ramsar site, Nepal. The Scientific World Journal. http://dx.doi.org/10.1155/2016/2605609

Barbier, E. B., Hacker, S. D., Kennedy, C., Koch, E. W., Stier, A. C., \& Silliman, B. R. (2011). The value of estuarine and coastal ecosystem services. Ecological Monograph, 81(2), 169 193. https://doi.org/10.1890/10-1510.1
Bhattacharya, S., Ganguli, A., Bose, S., \& Mukhopadhyay, A. (2012). Biodiversity, traditional practices and sustainability issues of East Kolkata Wetlands: A significance Ramsar site of West Bengal, (India). Reaserach and Reviews in BioSciences, 6(11), 340-347.

Bolund, P., \&Hunhammar, S. (1999). Ecosystem services in urban areas, Ecological Economics, $29,293-301$.

Brander, L., Gómez-Baggethun, E., MartínLópez, B., \& Verma, M. (2010). The economics of valuing ecosystem services and biodiversity. Geneva: The Economics of Ecosystems and Biodiversity - TEEB.

Clarkson B. R., Ausseil A. E., \&Gerbeaux, P. (2013). Wetland ecosystem services. In J. R. Dymond (Ed.) Ecosystem services in New Zealand - conditions and trends (pp. 192-202). Manaaki Whenua Press.

Das, S., Behera, B., \& Mishra, A. (2015).

Determinants of household use of wetland resources in West Bengal, India. Wetlands Ecology and Management, 23(5), 803-816. https://doi.org/10.1007/s11273-015-9420-8

Emerton, L. (2015). Economic valuation of wetlands: total economic value. In C. M. Finlayson et al., (Eds.), The Wetland Book (pp. 16). 10.1007/978-94-007-6172-8_301-1

Everard, M., Kangabam, R.., Tiwari, M. K., McInnes, R.., Kumar, R.., Talukdar. G. H., Dixon, H., Joshi, P., Allan, R., Joshi, D., \& Das. L. (2019). Ecosystem service assessment of selected wetlands of Kolkata and the Indian Gangetic Delta: multi-beneficial systems under differentiated management stress. Wetlands Ecology and Management, 27, 405-426. https://doi.org/10.1007/s11273-019-09668-1

Ghosh, K. (2016). Avian diversity and species richness in Khanyan and adjoining areas of Hooghly District, West Bengal. International Journal of Fauna and Biological Studies. 3(3), 119-126.

Maltby, E., \& Acreman, M. C. (2011). Ecosystem services of wetlands: pathfinder for a new paradigm. Hydrological Sciences Journal, 56(2), 1341-1359. 
https://doi.org/10.1080/02626667.2011.63101

4

Mandal, M. H. \& Siddique, G. (2018). Water birds at Purbasthali oxbow lake: A geographical study. Researchers World, IX (Special Issue), 719.

Mandal, M. H., Siddique, G., \& Roy, A. (2018). Threats and opportunities of ecosystem services: A geographical study of Purbasthali oxbow Lake. Journal of Geography, Environment and Earth Science International, 16(4), 1-24. 10.9734/JGEESI/2018/43229

Mangi, H. O. (2016). Estimation of monetary values of the ecosystem services flow at the tidal Elbe River. Advances in Ecology.1-8. http://dx.doi.org/10.1155/2016/6742786 MEA (Millennium Ecosystem Assessment) (2005). Ecosystems and Human Well-being: Synthesis. Island Press.

Mukherjee, S. (2008). Economic Valuation of a Wetland in West Bengal, India. International Water Management Institute- TATA Water Policy Research Program Seventh Annual Partners' Meet 1, MPRA, 254-266

Saha, M. (2016). A Study of the Wetlands of Burdwan Subdivision, West Bengal with Reference to Resource Potentialities and Employment Generation, Unpublished Ph. D. thesis, The University of Burdwan.

Sarkar, U., Nag, S. K., Das, M. K., Karnatak, G., \& Sudheesan, D. (2016). Conservation WetlandsAn Effective Climate Change Adaptation in India. Kolkata: ICAR- Central Inland Fisheries Research Institute.

Sharma, B., Rasul, G., \& Chettri, N. (2015). The economic value of wetland ecosystem services: Evidence from the Koshi Tappu Wildlife Reserve, Nepal. Ecosystem Services, 12, 84-93. https://doi.org/10.1016/j.ecoser.2015.02.007

Zedler, J. B., \& Kercher, S. (2005). Wetland resources: Status, trends, ecosystem services, and restorability. Annual Review of Environment and Resources, 30, 39-74.

https://doi.org/10.1146/annurev.energy.30.050 504.144248

\section{About the Authors}

Mehedi Hasan Mandal is currently working as an Assistant Professor at the Department of Geography, Krishnagar Government College. He has completed his M. Phil. from the University of Burdwan in 2017. At present, he is trying to assess the Ecosystem Services of the Floodplain Wetlands of Lower Ganges Plain.

Anup Kumar Dey is presently engaged in the $\mathrm{M}$. Phil, Delhi School of Economics, University of Delhi. He has completed his Masters from Department of Geography, the University of Burdwan in 2019.

Arindam Roy is presently working as a Senior Research Fellow in the Department of Geography, the University of Burdwan. He has completed M.Sc. from the Department of Geography, the University of Calcutta in 2014. He has published nearly a dozen research articles on various geographical issues in different International Journals.

Professor Giyasuddin Siddique has been working in the Department of Geography, the University of Burdwan, since 1999. He has nearly 60 research papers published in various esteemed National and International Journals, and he has also written six textbooks. Nine scholars have been awarded Ph.D, and six scholars have been awarded M. Phil. degree under his supervision. He is keenly interested in field-based research on forests, ecology, and many other contemporary environmental issues.

\section{Conflict of Interest}

The authors declare that there is no conflict of interest.

\section{Acknowledgement}

The authors gratefully acknowledge the support and co-operation of the local villagers and the participants of our field study residing on the banks of the selected wetlands. They also express their heartfelt gratitude to the anonymous reviewers and the editor for their valuable comments, suggestion, and assistance for improving the quality of the article. 


\section{Author Contribution Statement}

Mehedi Hasan Mandal (MHM), Anup Kumar Dey (AKD), Arindam Roy (AR) and Giyasuddin Siddique (GS) have collectively designed the study. AKD, AR and MHM collected the data/information through field investigation in different periods. MHM and AKD analysed the data and wrote the first draft of the paper. AR and GS have also incorporated their inputs to improve the quality of the article. After the guidance and supervision from GS, MHM further reviewed, edited and developed the final draft of the manuscript. All the authors read and approved the final manuscript. On behalf of the authors, the corresponding author declares that the author contributions mentioned above are correct, and all authors agree to the statements. 